\title{
Chemical constituents of Aspergillus sp EJC08 isolated as endophyte from Bauhinia guianensis and their antimicrobial activity
}

\author{
EDUARDO A.A. PINHEIRO ${ }^{1}$, JOSIWANDER M. CARVALHO ${ }^{1}$, DIELLEM C.P. DOS SANTOS $^{1}$, \\ ANDRÉ O. FEITOSA ${ }^{1}$, PATRÍCIA S.B. MARINHO ${ }^{1}$, GISELLE MARIA S.P. GUILHON ${ }^{1}$, \\ LOURIVALDO S. SANTOS ${ }^{1}$, AFONSO L.D. DE SOUZA ${ }^{2}$ and ANDREY M.R. MARINHO ${ }^{1}$ \\ ${ }^{1}$ Faculdade de Química, Universidade Federal do Pará, Rua Augusto Corrêa, no 1, 66075-110 Belém, PA, Brasil \\ ${ }^{2}$ Departamento de Química, Universidade Federal do Amazonas, \\ Av. General Rodrigo Octávio, 6200, 69077-000 Manaus, AM, Brasil
}

Manuscript received on February 27, 2012; accepted for publication on January 15, 2013

\begin{abstract}
The present work reports the isolation of five compounds from Aspergillus sp EJC08 isolated as endophytic from Bauhinia guianensis, a tipical plant of the Amazon. The compounds ergosterol (1), ergosterol peroxide (2), mevalolactone (3), monomethylsulochrin (4) and trypacidin A (5) were isolated by chromatographic procedures and identified by spectral methods of 1D and 2D NMR and MS. Compounds 3, 4 and 5 were tested against Escherichia coli, Pseudomonas aeruginosa, Bacillus subtilis and Staphylococcus aureus and showed good activity.
\end{abstract}

Key words: chemical constituents, antimicrobial assay, Aspergillus, Bauhinia guianensis.

\section{INTRODUCTION}

In recent decades have grown the number of studies about associations between plants and endophytic microorganisms, which by definition, live intra- and/or inter-cellularly without causing visible disease symptoms (Petrini et al. 1992). The accumulation of information about plantendophyte interaction has had special attention, since some species of endophytic microorganisms are producers of drugs such as antitumor and antibiotics, in addition to their important role in biological control of bacterial and fungal diseases (Azevedo et al. 2000). This interaction also provides, in some cases, resistance to pathogens

Correspondence to: Andrey Moacir do Rosario Marinho E-mail: andrey@ufpa.br
(Hallmann et al. 1997). Microorganisms have a wide biological and biochemical diversity and represent a resource not yet exploited.

The research to found new drugs beyond propitiating the advance, the basic research can contribute to technological development, as well as knowing that the diversity of the Brazilian biomes is little explored give Brazil a larger potential to discovery the activity compounds (Costa 2009). Brazil, with the grandeur of its coast, flora and by being holder of the largest tropical and wet tropical forest (the Amazon rainforest) on the planet, cannot abdicate its vocation for natural products. It is known that the highest biodiversity of plant species is found in Brazilian Amazon and it is estimated that about 
$80 \%$ of plants are infested by microorganisms (Stierle et al. 1995), which makes this region rich in microorganism species, many have not yet reported in the literature.

This paper reports the isolation and structural identification of five compounds of the fungus Aspergillus sp EJC08 (Figure 1) isolated as endophyte from Bauhinia guianensis, a typical plant of the Amazon known as "escada de jabuti". It is used in folk medicine for treatment of infections, pain processes and diabetes (Amorozo and Gely 1988). The compounds were tested by first time against the bacteria E. coli, P. aeruginosa, B. subtilis and $S$. aureus and showed good activity.

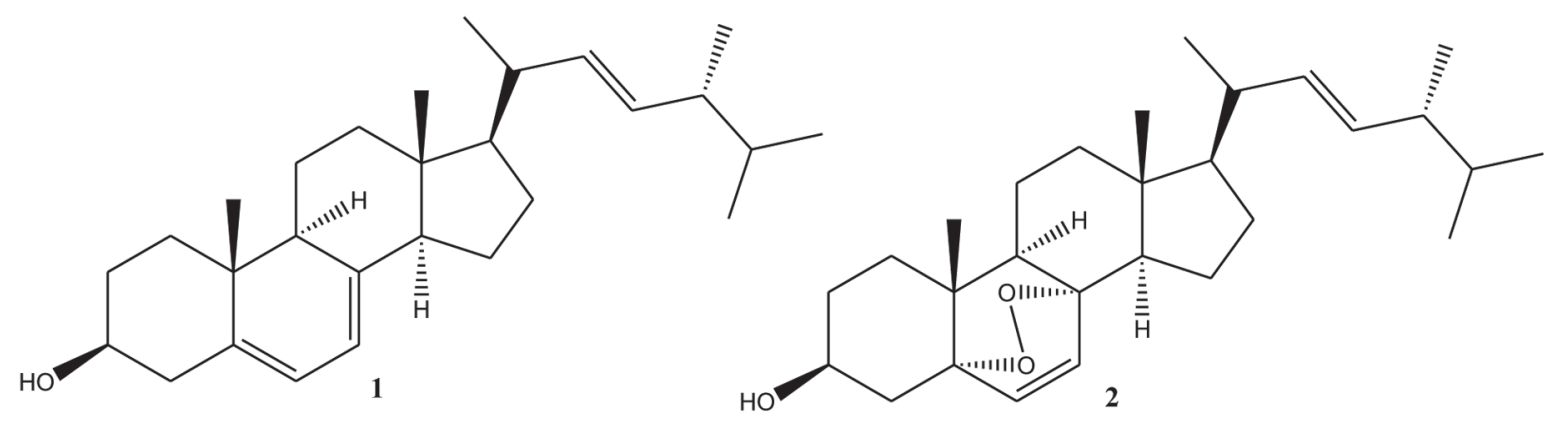

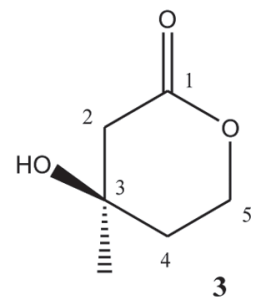

3

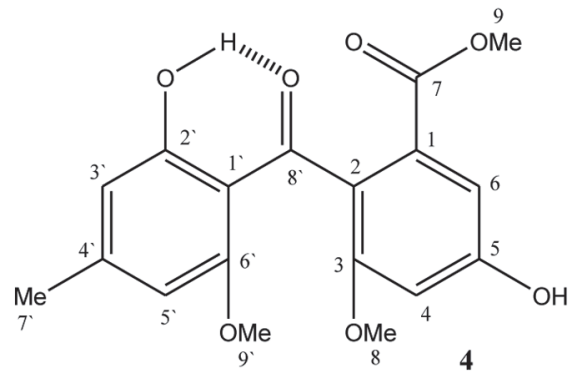

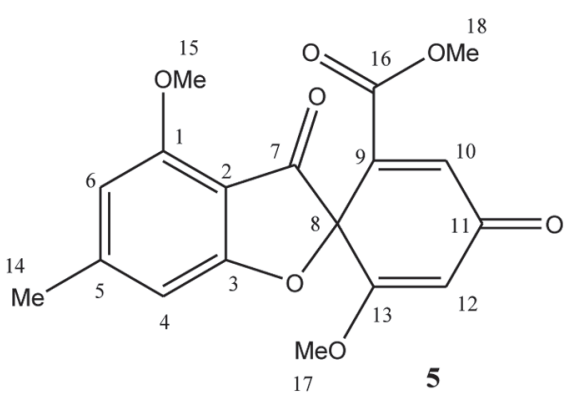

Figure 1 - compounds isolated from Aspergillus sp EJC08.

\section{MATERIALS AND METHODS}

\section{GENERAL PROCEDURES}

The IR spectrum was measured in IS-10 Thermo ${ }^{\circledR}$ spectrophotometer (Thermo Fisher Scientific, $\mathrm{UK})$ in $\mathrm{KBr}$ pellets. APCIMS data were acquired in positive mode using a TQS Quantum Access Thermo $^{\circledR} \quad$ (Thermo Fisher Scientific, UK) instrument. Experiments of 1D and 2D NMR were obtained on a Varian Mercury-300 spectrometer (Varian, Inc., USA) in $\mathrm{CDCl}_{3}$.

\section{MiCROORGANISM}

Aspergillus sp was obtained from the collection of the Laboratório de Bioensaio e Química de Microorganismos (LaBQuiM), Faculdade de Química - Universidade Federal do Pará. This collection contains isolates from Bauhinia guianensis. One strain is deposited in the LaBQuiM with the code EJC08.

Culture of Aspergillus SP in Rice AND ChemicAl CONSTITUENTS ISOLATION

Twenty-two Erlenmeyer flasks $(1,000 \mathrm{~mL})$ containing $200 \mathrm{~g}$ rice (Tio João ${ }^{\circledR}$ ) and $125 \mathrm{~mL}$ distilled water per flask were autoclaved for $45 \mathrm{~min}$ at $121^{\circ} \mathrm{C}$. Small cubes of PDA medium containing mycelium of Aspergillus sp EJC08 were added in 20 Erlenmeyer flasks under sterile condition. Two flasks were used as control. After 30 days of growth 
at $25^{\circ} \mathrm{C}$ the biomass obtained was macerated with hexane, ethyl acetate and methanol. The ethyl acetate was evaporated under reduced pressure, producing a yellowish residue $(9.9 \mathrm{~g})$. After successive fractionations the ethyl acetate extract on silica gel chromatography column eluted with hexane, ethyl acetate and methanol in polarity gradient were obtained the compounds ergosterol (1), ergosterol peroxide (2), mevalolactone (3), monomethylsulochrin (4) and trypacidin A (5).

\section{ANTIBACTERIAL BIOASSAY}

Microorganisms' susceptibly to the compounds test were determined by microbroth dilution assay as recommended by the Subcommittee on Antifungal Susceptibility Testing of the US National Committee for Clinical Laboratory Standards (NCCLS 1997). The compounds were assayed against Escherichia coli (ATCC 25922), Pseudomonas aeruginosa (ATCC 27853), Bacillus subtilis (ATCC 6633) and Staphylococcus aureus (ATCC 25923). Penicillin, vancomycin and tetracycline $\left(25 \mu \mathrm{g} \cdot \mathrm{mL}^{-1}\right.$ each) were used as positive controls; the cultivation medium (MHB only) was used as negative control.

\section{RESULTS AND DISCUSSION}

\section{CHEMICAL CONSTITUENTS IDENTIFICATION}

Compounds 1 and 2 were obtained from the ethyl acetate extract of the biomass produced by Aspergillus sp EJC08 cultivated in rice (Tio João ${ }^{\circledR}$ ). These substances are solid crystal and their NMR and MS data are perfectly identical to those described in the literature for ergosterol (1) and ergosterol peroxide (2) (Yue et al. 2001, Kawagishi et al. 1988).

The compound 3 was isolated as yellowish oil. The ${ }^{1} \mathrm{H}$ NMR spectrum showed characteristic signals for carbinolic hydrogens at $\delta 4.60(d d d, 11.3$, 8.9 and $5.9 \mathrm{~Hz}, \mathrm{H}-5 \mathrm{a})$ and $\delta 4.35$ (ddd, 11.3, 5.0 and $4.4 \mathrm{~Hz}, \mathrm{H}-5 \mathrm{~b}$ ) both integrating for one hydrogen. In HSQC spectrum was found that these hydrogens were connected to the same carbon (C-5, $\delta$ 66.2). Signals at $\delta 2.67(d t, 17.4$ and $1.3 \mathrm{~Hz}, \mathrm{H}-2 \mathrm{a})$ and $\delta$ $2.51(d, 17.4 \mathrm{~Hz}, \mathrm{H}-2 \mathrm{~b})$ are common to neighboring hydrogens to carboxyl group. The signal singlet at $\delta 1.39$ was attributed to the presence of a methyl group and shows correlation of HMBC with the carbon C-3 $(\delta$ 69.7). It is also seen a multiplet signal at $\delta 1.91(\mathrm{H}-4)$. The ${ }^{13} \mathrm{C}$ NMR spectrum showed a typical signal to lactone carbonyl at $\delta$ 171.2, in addition to the signs at $\delta 67.9$ and $\delta 66.2$ that through DEPT spectrum was found to be a non-hydrogenated carbon and methylenic carbon, respectively. The mass spectrum APCI (+) showed $m / z 131[\mathrm{M}+\mathrm{H}]^{+}$suggesting the molecular formula $\mathrm{C}_{6} \mathrm{H}_{10} \mathrm{O}_{3}$ for substance. Through the correlations observed in the HMBC experiment was possible determine the structure of 3 as being mevalolactone (Marinho et al. 2007).

The compound 4 was isolated as a pale yellow crystalline solid. In the ${ }^{1} \mathrm{H}$ NMR spectrum was observed signal at $\delta 12.98(s)$ assigned to a hydroxyl chelated by hydrogen bond, signals for methoxyl groups at $\left.\delta 3.37\left(s, \mathrm{OMe}^{\prime}\right)^{\prime}\right), \delta 3.68(\mathrm{~s}$, OMe-9) and $\delta 3.70(s, \mathrm{OMe}-8)$, and a signal at $\delta$ $2.29\left(s, \mathrm{Me}-7^{\prime}\right)$ commonly attributed to the methyl bonded to an aromatic system. In addition, were observed aromatic signals at $\delta 6.62(d, 2.1, \mathrm{H}-4)$ and $7.02(d, 2.1, \mathrm{H}-6)$, whose coupling constant indicated that they are meta-related. Were also observed signals at $\delta 6.45(b r s)$ and $6.06(b r s)$ which in the COSY experiment were correlate with each other and with a methyl signal, indicating a methyl group at C-7'. Through the HMBC correlations observed between H-6 and the carbons C-2 ( $\delta$ 128.4), C-7 ( $\delta$ 166.1) and C-5 ( $\delta$ 156.1), combined with the correlations of methoxyl group at C-9 with C-7, an acetate group was positioned at $\mathrm{C}-1$ carbon. The HMBC correlations of hydrogen H-3' with the carbons C-1' ( $\delta 110.4), \mathrm{C}-5$ '( $\delta$ 102.9) and Me-7' along with the HMBC correlations presented for the chelated -OH group $(\delta$ 12.98) with the carbons C-2 ( $\delta$ 164.1) and C-3' ( $\delta$ 110.9), 
showed that this $-\mathrm{OH}$ group was located at $\mathrm{C}-2$ '. In ${ }^{13} \mathrm{C}$ NMR spectrum is still observed a signal at $\delta 199.4$ assigned to benzophenonic carbonyl C-8'. APCI (+) mass spectrum of 4 showed $\mathrm{m} / \mathrm{z} 347$ $[\mathrm{M}+\mathrm{H}]^{+}$which along with NMR data has led to the molecular formula $\mathrm{C}_{18} \mathrm{H}_{18} \mathrm{O}_{7}$. The compound 4 was identified as benzophenone monomethylsulochrin. According to the literature (Ma et al. 2004) benzophenone monomethylsulochrin has important anti-Helicobacter pylori activity.

The substance 5 was isolated as a white crystalline solid soluble in dichloromethane. Analysis of the ${ }^{1} \mathrm{H}$ NMR spectrum showed two doublets signals meta-related at $\delta 6.55(2.1 \mathrm{~Hz})$ and $\delta 6.37(2.1 \mathrm{~Hz})$ assigned to the hydrogens $\mathrm{H}-4$ and H-6 of the aromatic ring. Doublet signals at $\delta 5.77$ $(1.2 \mathrm{~Hz})$ and $\delta 7.10(1.2 \mathrm{~Hz})$ are weakly coupled and were assigned to hydrogens $\mathrm{H}-12$ and $\mathrm{H}-10$, respectively. Singlet signals were also observed and attributed to the methyl hydrogens of three methoxyl groups at $\delta 3.66(\mathrm{OMe}-17), \delta 3.69(\mathrm{OMe}-$ $18)$ and $\delta 3.95$ (OMe-15). In addition to the singlet signal at $\delta 2.44$ typically attributed to the methyl hydrogens attached to the aromatic system (Me14). In the ${ }^{13} \mathrm{C}$ NMR spectrum can be observed signals relating to 18 carbons, which along with mass spectrum data APCI $(+) \mathrm{m} / z 345[\mathrm{M}+\mathrm{H}]^{+}$was possible to propose a molecular formula $\mathrm{C}_{18} \mathrm{H}_{16} \mathrm{O}_{7}$ to 5. The analysis of COSY spectra, HSQC and HMBC allowed determining the structure of 5. In the COSY spectrum were observed the correlations of H-4 and H-6 among each with the methyl Me14 confirming that these groups are present on the same aromatic ring. Also in the COSY spectrum was observed the correlation between the hydrogens H-10 and H-12. ${ }^{1} \mathrm{H}$ NMR data for 5 were compared to the literature and showed all the similarity to the trypacidin A (Balan et al. 1965). The assignments of signals of $1 \mathrm{H} \mathrm{NMR}$ and $13 \mathrm{C}$ were performed through correlations analyzes of COSY, HSQC and HMBC. In the HMBC spectrum was observed the correlation of H-6 with the signals of carbons at $\delta 105.5(\mathrm{C}-4), 23.2$ (C-14), $158.3(\mathrm{C}-1)$ and a $\mathrm{J}^{4}$ correlation with the signal at $\delta 190.0$, assigned to carbonyl C-7. The correlation of methoxyl at C-15 $(\delta 3.95)$ with the signal at $\delta 158.3$ allowed locating it at $\mathrm{C}-1$. The signal at $\delta 84.0$ was assigned to the spiro carbon $\mathrm{C}-8$. The trypadicin can be formed through of the oxidative coupling of monomethylsulochrin, Figure 2 (Dewick 1997). The ${ }^{1} \mathrm{H}$ and ${ }^{13} \mathrm{C}$ NMR data of 5 are shown in Table I.

TABLE I

data of the NMR ${ }^{1} \mathrm{H}$ and ${ }^{13} \mathrm{C}$ to $5\left(300 \mathrm{MHz}, \mathrm{CDCl}_{3}\right)$.

\begin{tabular}{c|c|c}
\hline $\mathbf{n}^{\circ}$ & $\mathbf{H}(\mathbf{m u l t}, \boldsymbol{J}$ in Hz) & $\mathbf{C}$ \\
\hline $\mathbf{1}$ & & 158.3 \\
$\mathbf{2}$ & & 108.3 \\
$\mathbf{3}$ & & 174.3 \\
$\mathbf{4}$ & $6.55(d, 2.1)$ & 105.5 \\
$\mathbf{5}$ & & 152.2 \\
$\mathbf{6}$ & $6.37(d, 2.1)$ & 105.3 \\
$\mathbf{7}$ & & 190.0 \\
$\mathbf{8}$ & & 84.0 \\
$\mathbf{9}$ & & 138.2 \\
$\mathbf{1 0}$ & $7.10(d, 1.2)$ & 137.1 \\
$\mathbf{1 1}$ & & 185.7 \\
$\mathbf{1 2}$ & $5.77(d, 1.2)$ & 103.9 \\
$\mathbf{1 3}$ & & 169.4 \\
$\mathbf{1 4}$ & $2.44(s)$ & 23.2 \\
$\mathbf{1 5}$ & $3.95(s)$ & 56.1 \\
$\mathbf{1 6}$ & & 163.5 \\
$\mathbf{1 7}$ & $3.66(s)$ & 56.7 \\
$\mathbf{1 8}$ & & 52.8 \\
\hline & & \\
\hline
\end{tabular}

ANTIMICROBIAL ACTIVITY

The antibacterial activities of mevalolactone (3), monomethylsulochrin (4) and trypacidin A (5) were examined in the presence of E. coli, P. aeruginosa, $B$. subtilis and $S$. aureus and showed good activity (Table II). Penicillin, vancomycin and tetracycline (25 $\mu \mathrm{g} \cdot \mathrm{mL}^{-1}$ each) were used as positive controls and showed bactericidal effect for all bacteria at this concentration. 


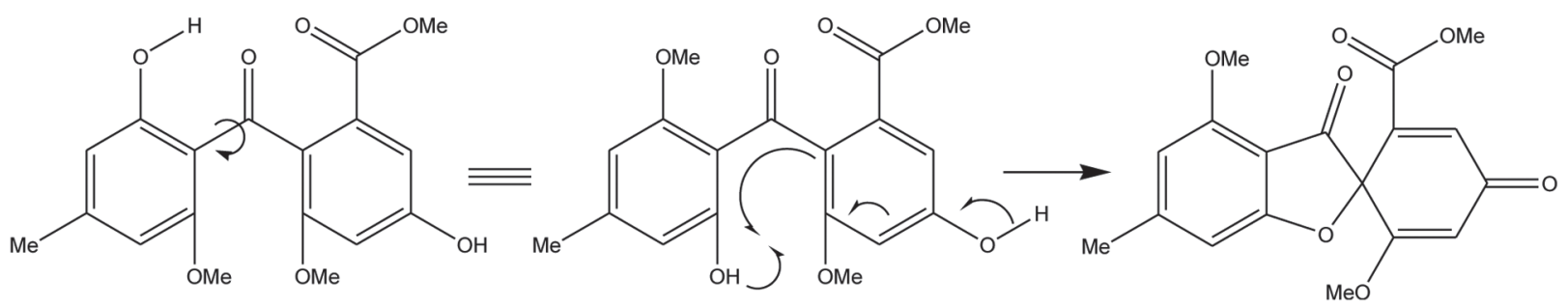

Figure 2 - trypacidin formation through oxidative coupling of monomethylsulochrin.

TABLE II

Bacteria growth behavior in the presence of compounds 3, 4 and 5 at different concentrations.

\begin{tabular}{|c|c|c|c|c|c|c|c|c|c|c|c|c|}
\hline & \multicolumn{3}{|c|}{ compounds } & \multicolumn{3}{|c|}{ compounds } & \multicolumn{3}{|c|}{ compounds } & \multicolumn{3}{|c|}{ compound } \\
\hline $\begin{array}{l}\text { Concentration } \\
{\left[\mu \mathrm{g} . \mathrm{mL}^{-1}\right]}\end{array}$ & 3 & 4 & 5 & 3 & 4 & 5 & 3 & 4 & 5 & 3 & 4 & 5 \\
\hline 500.00 & - & $=$ & $=$ & - & - & - & - & $=$ & $=$ & - & - & - \\
\hline 250.00 & - & $=$ & $=$ & - & - & - & - & $=$ & $=$ & - & - & - \\
\hline 125.00 & - & $=$ & $=$ & - & - & - & - & $=$ & $=$ & - & - & - \\
\hline 62.50 & - & $=$ & $=$ & - & - & - & - & $=$ & $=$ & - & - & - \\
\hline 31.25 & + & $=$ & $=$ & - & - & - & - & $=$ & $=$ & - & - & + \\
\hline 15.62 & + & + & $=$ & + & + & + & - & - & + & - & + & + \\
\hline 7.81 & + & + & + & + & + & + & - & + & + & - & + & + \\
\hline Bacteria & \multicolumn{3}{|c|}{ E. coli } & \multicolumn{3}{|c|}{ P. aeruginosa } & \multicolumn{3}{|c|}{ B. subtilis } & \multicolumn{3}{|c|}{ S. aureus } \\
\hline
\end{tabular}

$=$ bactericidal effect, - bacteriostatic effect, + no active.

\section{ACKNOWLEDGMENTS}

The authors thank the Fundação Amazônia Paraense de Amparo à Pesquisa (FAPESPA), Conselho Nacional de Desenvolvimento Científico e Tecnológico (CNPq), Coordenação de Aperfeiçoamento de Pessoal de Ensino Superior (CAPES) and Ministério da Saúde (MS) for financial support.

\section{RESUMO}

Neste trabalho estamos reportando o isolamento de cinco compostos de Aspergillus sp EJC08 isolado como endofítico de Bauhinia guianensis uma planta típica da Amazônia. Os compostos ergosterol (1), peróxido de ergosterol (2), mevalolactona (3), monometilsulocrina (4) e tripacidina A(5) foram isolados através de procedimentos cromatográficos e identificados por métodos espectrais de RMN 1D e 2D e EM. Os compostos 3, 4 e 5 foram testados contra Escherichia coli, Pseudomonas aeruginosa, Bacillus subtilis e Staphylococcus aureus e mostraram boa atividade.

Palavras-chave: constituintes químicos, ensaio antimicrobiano, Aspergillus, Bauhinia guianensis.

\section{REFERENCES}

Amorozo MCM AND Gely A. 1988. Uso de Plantas Medicinais por Caboclos do Baixo Amazonas. Barcarena-PA, Brasil. Bol Mus Para Emilio Goeldi, Sér Bot 4: 47-131.

AzEVEdo JL, MACChERONI JR, PEREIRA JO AND ARAÚJo WL. 2000. Endophytic microorganisms: a review on insect control and recent advances on tropical plants. Electron $\mathrm{J}$ Biotechnol 3: 40-66.

Balan J, KJaER A, Kovac S AND Shapiro RH. 1965. The Structure of Trypacidin. Acta Chem Scand 19: 528-530.

COSTA PRR. 2009. Produtos naturais como ponto de partida para a descoberta de novas substâncias bioativas: Candidatos a fármaco com ação antiofídica, anticâncer e antiparasitária. Rev Virtual Quim 1: 58-66.

DEWICK PM. 1997. Medicinal natural products: a biosynthetic approach. New York: J Wiley \& Sons, New York, USA, p. 70. 
Hallmann J, QuAdT-Hallmann A, MahaffeE WF AND KLOEPPER JW. 1997. Bacterial endophytes in agricultural crops. Can J Microbiol 43: 895-914.

KaWAGishi H, Katsumi R, SAZaWA T, Mizuno T, Hagiwara T AND NAKAMURA T. 1988. Cytotoxic Steroids from the Mushroom Agaricus blazei. Phytochemistry 27: $2777-$ 2779.

MA YM, LI Y, LIU YC AND SONG RXT. 2004. Anti-Helicobacter pylori metabolites from Rhizoctonia sp. CY064, an endophyptic fungus in Cynodon dactylon. Fitoterapia 75: 451-456.

MARINHO AMR, MARINHO PSB AND RODRIGUES FILHO E. 2007. Constituintes Químicos de Penicillium sp, um Fungo Endofítico Isolado de Murraya paniculata (Rutaceae). Rev Cienc Exatas Nat 9: 189-199.
NCCLS - NATIONAL COMMITTEE FOR CLINICAL LABORATORY STANDARDS. 1997. Methods for Dilution and Antimicrobial Susceptibility Tests for Bacteria that Grow Aerobically, NCCLS Approved Standard M7-A4, Wayne, PA.

Petrini O, Sieber TN, Toti L And Viret O. 1992. Ecology, metabolite production, and substrate utilization in endophytic fungi. Natural Toxins 1: 185-196.

Stierle A, Strobel GA, Stierle D, Grothaus P AND BIGNAMI G 1995. The search for a taxol-producing microorganism among the endophytic fungi of the pacific yew, Taxus brevifolia. J Nat Prod 58: 1315-1324.

YuE J, CHEN S, Lin Z AND Sun H. 2001. Sterol from the fungos Lactarium volemus. Phytochemistry 56: 801-806. 